\title{
Levamisole-induced vasculitis with ecchymosis and necrosis syndrome from contaminated cocaine
}

\author{
Nayan Desai, ${ }^{1}$ Monaliben Patel, ${ }^{1}$ Shivang Desai, ${ }^{2}$ Elizabeth Cerceo ${ }^{1}$ \\ ${ }^{1}$ Department of Medicine, Cooper University Hospital, Camden, New Jersey, USA \\ ${ }^{2}$ Department of Radiodiagnosis, Padmashree Dr D Y Patil Univeristy, Mumbai, Maharashtra, India \\ Correspondence to Dr Nayan Desai, nayandesai_16@yahoo.co.in
}

\section{DESCRIPTION}

A 43-year-old-man presented with 1-month history of progressive erythematous painful lesions over multiple sites involving bilateral lower extremities, trunk and pinnae. He was a chronic cocaine user; last use was 3 days prior to presentation. On examination he had bilateral large retiform, geometric, dusky, erythematous, tender plaques with central necrosis and ecchymosis over aforementioned areas (figures 1 and 2). There was significant necrosis of helical rims of pinnae. (figure 3). He had leucopenia with neutropenia on complete blood count. Perinuclear-antineutrophil cytoplasmic antibody ( $\mathrm{p}$-ANCA) was positive. Urine drug screen was positive for cocaine and levamisole was detected by gas chromatography technique in the patient's urine. Biopsy of skin lesions showed acute necrotising neutrophilic vasculitis involving small and medium vessels in both dermis and subcutaneous tissue with fibrin thrombi and fibrinoid necrosis. A diagnosis of levamisole-induced vasculitis with ecchymosis and necrosis syndrome was made from contamination of cocaine with levamisole. Levamisole has been identified as a contaminant in $70 \%$ of cocaine seized in the USA. ${ }^{1}$ The prevalence of levamisole as a contaminant of cocaine may be related to its similar appearance to cocaine and stimulant effects from dopamine release. It is detected by gas chromatography mass spectroscopy technique in urine specimens. ${ }^{2}$ Toxicity causes cutaneous, haematological and neurological manifestations.

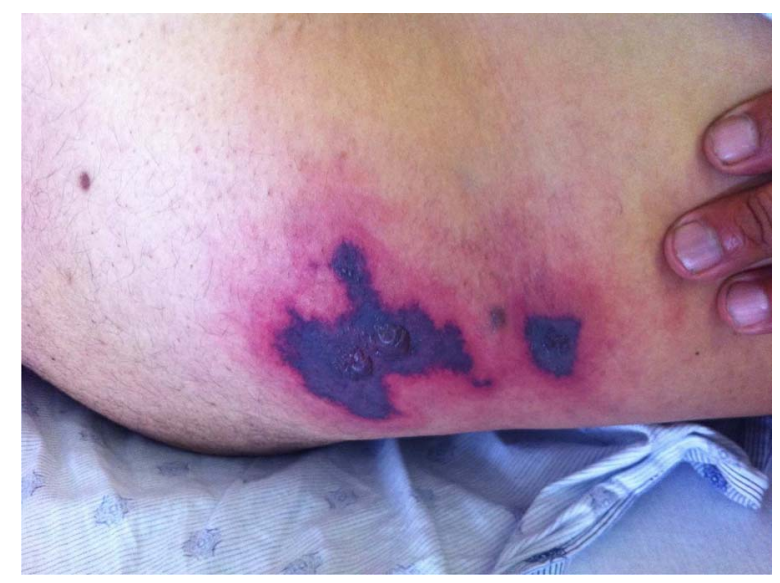

Figure 1 Skin ecchymosis and retiform purpurae.

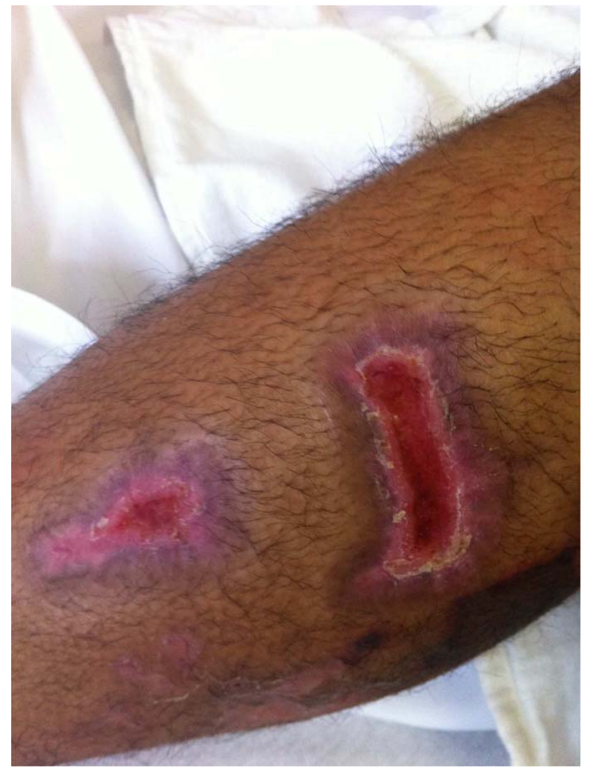

Figure 2 Skin necrosis.

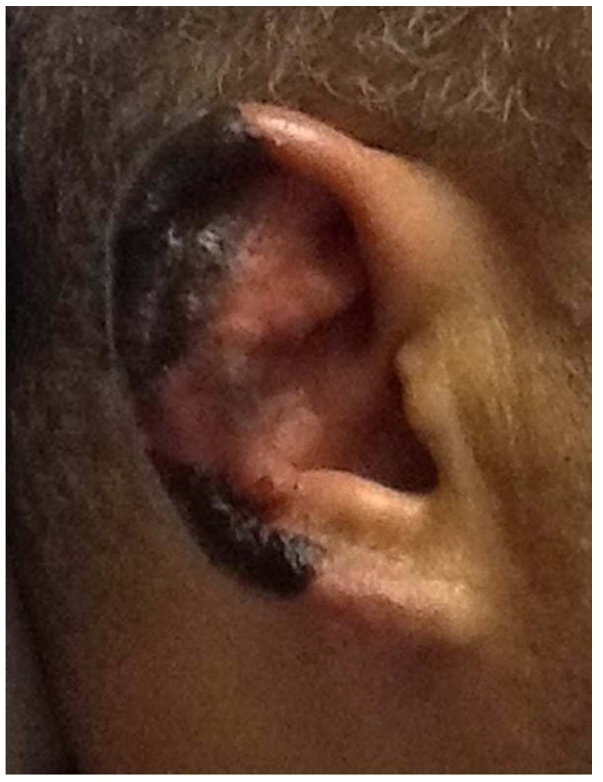

Figure 3 Necrosis of helical rims of pinnae. 


\section{BMJ Case Reports}

The spectrum of cutaneous involvement includes development of purpuric papules, ecchymosis, skin necrosis leading to ulceration and secondary infection. Bilateral ear involvement, especially helical margins, is seen in the majority of patients. ${ }^{3}$

\section{Learning points}

- Identify complications of cocaine use.

- Differential diagnosis of causes for necrotising vasculitis.
Competing interests None.

Patient consent Obtained.

\section{REFERENCES}

1. Centers for Disease Control and Prevention. Agranulocytosis associated with cocaine use-four States, March 2008-November 2009. MMWR Morb Mortal Wkly Rep 2009;58:1381-5.

2. Trehy ML, Brown DJ, Woodruff JT, et al. Determination of levamisole in urine by gas chromatography-mass spectrometry. J Anal Toxicol 2011;35:545-50.

3. Jacob RS, Silva CY, Powers JG, et al. Levamisole-induced vasculopathy: a Report of 2 cases and a novel histopathologic finding. Am J Dermatopathol 2011;35:208-13.

Copyright 2012 BMJ Publishing Group. All rights reserved. For permission to reuse any of this content visit

http://group.bmi.com/group/rights-licensing/permissions.

BMJ Case Report Fellows may re-use this article for personal use and teaching without any further permission.

Please cite this article as follows (you will need to access the article online to obtain the date of publication).

Desai N, Patel M, Desai S, Cerceo E. Levamisole-induced vasculitis with ecchymosis and necrosis syndrome from contaminated cocaine. BMJ Case Reports 2012;10.1136/bcr-2012-007319, Published XXX

Become a Fellow of BMJ Case Reports today and you can:

- Submit as many cases as you like

- Enjoy fast sympathetic peer review and rapid publication of accepted articles

- Access all the published articles

- Re-use any of the published material for personal use and teaching without further permission

For information on Institutional Fellowships contact consortiasales@bmjgroup.com

Visit casereports.bmj.com for more articles like this and to become a Fellow 